apical filum; terminal segment slightly reduced, with a length about twice its diameter and tapering suddenly to an obtuse apex; the surface of this segment is nearly covered with very irregular, anastomosing circumfili. Palpi yellowish, basal segment roundly quadrate, the second segment reduced, conical. Mesonotum reddish brown. Scutellum brownish, yellowish apically, postscutellum brownish yellow. Abdomen sparsely haired, dark brown. Halteres and coxæ yellowish. Legs mostly yellowish straw. Ovipositor when extended about as long as the abdomen, the terminal portion moderately stout and with ndistinct, inarrowly rounded apical lobes.

This species departs from the typical Hormomyia in the greatly produced ovipositor of the female and it is possible that it, with related forms, should be referred to a distinct genus.

Type, C. a2453.

\title{
SOME NEW NORTH AMERICAN ANAPHORINÆ.
}

BY WM. BARNES, M.D., AND J. MCDUNNOUGH, PH.D., DECATUR, ILL.

In sorting over a large accumulation of material belonging to the Tineid group called by Walsingham Anaphorina, we discovered several species which did not agree with the descriptions of any known North American species; these we venture to describe as new. We have followed Walsingham in the generic references, although Busck states that these genera are not tenable; we feel, however, that Walsingham's genera serve at least to define the position of the species in the group rather more clearly than if we had employed - a more general term.

Neolophus antonellus, sp. nov. (Fig. 3.)

$0^{7}$.- Antennæ strongly serrate and fasciculate; palpi roughhaired, upturned to well above front and rather closely appressed, ochreous, deep brown at base; collar brown at base, ochreous apically; thorax brown centrally, this portion rather sharply defined by pale ochreous patagia with light brown center. Primaries light brown with broad, very prominent pale yellowish stripe from base of wing through the fold to approximately the end of cell; upper margin of this stripe is rather even, bordered by a black line which curves slightly upwards and ends in a black discocellular dot; 
lower margin irregular, the stripe projecting slightly about center of wing in small quadrate patch towards inner margin, bordered basally with blackish and with brown patch beyond the projection; outer boundaries of stripe diffuse, two faint narrow black lines extending beyond it on each side of vein 4 to termen; slight sprinkling of gray scales above anal angle; costa and inner margin shaded with black-brown basally; indistinct series of marginal dots extending from costa before apex to anal angle; fringes brown, cut by ochreous. Secondaries smoky ochreous at base. Beneath smoky brown tinged with ochreous. Expanse $33 \mathrm{~mm}$.

Habitat: San Antonio, Texas: $1 \sigma^{\top}$. Type, Coll. Barnes. Eulepiste pyramellus, sp. nov. (Fig. 4.)

$\sigma^{7}$.-Antennæ annulate; palpi rather smooth, upturned to above front, but not appressed; front pale ochreous, thorax darker; primaries an admixture of pale gray and brown scales, maculation very indefinite and indistinct, in well-marked individuals consisting of a brownish blotch in cell near base, another at end of cell and a third midway between these two above inner margin, these latter are at times connected outwardly by a whitish oblique waved line which is usually more or less obsolete; indistinct costal and terminal dark dots; secondaries and underside unicolorous smoky brown. Expanse $23 \mathrm{~mm}$.

Habitat: Pyramid Lake, Nevada. $4 \sigma^{x}$. Type, Coll. Barnes.

The species appears to be intermediate between hirsutus Bsk. and occidens Bsk:

Pseudanaphora quadrellus, sp. nov. (Figs. 1, 2.)

$\sigma^{7}$.-Antennæ very slightly serrate below, palpi upturned, roughly haired, brown; thorax chocolate-brown; primaries chocolate brown shaded with pale ochreous especially along inner margin and termen; costa with alternate strixe of chocolate-brown and ochreous; slight ochreous tinge in cell; dark discocellular dash; inner margin brozdly ochreois, more or less striate with brown, upper edge of th's oc reo s stripe irregular with prominent blunt tooth of groand-cclour projecting downward towards middle of inner margin; before and after this tooth the margin is rounded, bent sharply upwards. beyond origin of vein 3 as far as vein 7 , bending again at right angles and attaining termen below apex, forming a large subquadrate terminal ochreous patch; faint ter- 
minal row of dark dots; fringes checkered brown and ochreous with pale basal line. Secondaries pale smoky brown with ochreous terminal line and checkered fringes. Beneath smoky brown, costa of primaries apically ochreous with 3 or 4 brown striæ, narrow terminal ochreous line, secondaries and fringes as above.

‥-Palpi short, hairy, porrect; primaries more uniform chocolate brown with only faint traces of ochreous along inner margin; a paling of the ground colour represents the quadrate terminal patch so prominent in the $\sigma^{7}$. Expanse $\sigma^{7} 25 \mathrm{~mm}$. † $28 \mathrm{~mm}$.

Habitat: Palmerlee, Ariz. $7 \sigma^{\top}, 3$ ㅇ. Types, Coll. Barnes.

The species is allied to davisellus Beut., but should be readily distinguished by the dark apex and subquadrate ochreous terminal patch with sharply defined inner edge. The malesvary in the amount of brown striations on the ochreous area in some there are scarcely any, in others they show a tendency to obscure this area more or less completely.

\section{EUGONIA CALIFORNICA BDV. IN THE PACIFIC NORTHWEST.}

During the summer of 1912 there was an unusual occurrence of the caterpillars of Eugonia californica in a number of places throughout the states of Washington, Idaho, and also British Columbia. They were reported as being present "by the millions" and defoliating the buckbrush or ceanothus (Ceanothus velutinus). It was even reported that the caterpillars were blocking the trains at Clayton, a village about 30 miles north of Spokane, Wash. This story was not exaggerated in the least, as I had occasion to ascertain.

On the 18th of June I visited the field of devastation at Clayton. When I first arrived at the place, I thought the caterpillars to be those of Vanessa antiopa, but such they did not prove to be. I saw that there were a great many of the caterpillars and started to step off the distance across the small area ahead of me, but I soon found that it was not a matter of yards or rods, but of miles. As far as could be seen to the westward, the ceanothus looked as if it had been scorched by fire. All the bright, green glossy leaves had been eaten, and the branches were entirely bare except for the millions of crawling, spiny, dark caterpillars. They were crawling 


\section{$2 \mathrm{BHL}$ Biodiversity Heritage Library}

1913. "Some new American Anaphorinae." The Canadian entomologist 45, 419-421. https://doi.org/10.4039/Ent45419-12.

View This Item Online: https://www.biodiversitylibrary.org/item/22231

DOI: https://doi.org/10.4039/Ent45419-12

Permalink: https://www.biodiversitylibrary.org/partpdf/27110

\section{Holding Institution}

MBLWHOI Library

\section{Sponsored by}

MBLWHOI Library

\section{Copyright \& Reuse}

Copyright Status: NOT_IN_COPYRIGHT

This document was created from content at the Biodiversity Heritage Library, the world's largest open access digital library for biodiversity literature and archives. Visit BHL at https://www.biodiversitylibrary.org. 